\title{
TINJAUAN BUDAYA PADA BENTUK RUMAH VERNAKULAR DI JABUNGAN SEMARANG
}

\author{
Hana Faza Surya Rusyda ${ }^{1}$, Agus Dody Purnomo ${ }^{1}$, Putri Jembarati ${ }^{1}$ \\ ${ }^{1}$ Desain Interior, Fakultas Industri Kreatif, Universitas Telkom, Jl. Telekomunikasi No. 1 \\ Dayeuh Kolot, Kab. Bandung 40257 \\ *hanafsr@telkomuniversity.ac.id
}

Diterima: 17-08-20202 Direview : 13-11-2020 Direvisi : 05-12-2020 Disetujui: 29-12-2020

ABSTRAK. Arsitektur Vernakular merupakan arsitektur yang tumbuh dan berkembang berdasarkan kebutuhan dari penggunanya. Arsitektur vernakular sering disamakan artinya dengan arsitektur tradisional. Arsitektur Tradisional merupakan bagian dari arsitektur vernakular namun arsitektur vernakular tidak selalu berbentuk tradisional. Arsitektur Vernakular yang ada di Indonesia sangat beragam, antara lain berupa hunian atau rumah. Pokok Bahasan pada penelitian ini adalah arsitektur vernakular berupa rumah. Rumah vernakular merupakan bangunan warisan yang mempunyai bentuk menyerupai rumah tradisional pada daerahnya. Rumah vernakular adalah suatu artefak yang dapat digali lagi untuk mendapatkan simbol dan mengetahui detail maknanya. Rumah vernakular yang ada di daerah Jawa mencerminkan status sosial dan kondisi ekonomi pemiliknya. Ini terlihat dari bentuk, elemen dan karakteristiknya. Dalam perkembangannya, sebuah rumah akan menyesuaikan dengan kebutuhan pemilik yang terlihat pada penambahan ruang-ruang. Seperti yang ada di daerah Semarang Selatan, Jabungan, Semarang. Penelitian ini bertujuan untuk menggali lebih dalam akan kajian budaya dari suatu rumah vernakular. Penelitian ini menggunakan teori Amos Rapoport yang berkaitan dengan rumah. Metode penelitian menggunakan deskiptif analisis, dengan pengumpulan data dari studi literatur dan studi lapangan dengan cara dokumentasi dan wawancara. Simpulan yang didapat berupa suatu temuan mengenai kajian hubungan budaya dan lingkungan terhadap bentuk rumah vernakular dan elemen arsitekturnya yang ada yang ada di Jabungan, Semarang.

Kata kunci: Budaya, Rumah Vernakular, Semarang

ABSTRACT. Vernacular house is categorized as a heritage building due to its traditional form. A vernacular house is an artifact that can be dug deeper to find out the meaning of each symbol in its details. In Javanese culture, vernacular houses reflect their owner's social status and economic condition. It can be seen in its form, elements, and characteristics. In the present, there are several changes according to the owner's needs seen in the addition of several rooms. As an example, this condition happened at Jabungan, South Semarang. Therefore, the purpose of the study is to examine the cultural elements in a vernacular house, which is based on the Amos Rapoport Theory. This method is descriptive-analytical, with data obtained from literature studies and field studies employing documentation and interviews. The results obtained in this study are the relationship of culture and environment to the form of vernacular houses and architectural elements in the Jabungan, Semarang.

Keywords: Culture, Vernacular House, Semarang

\section{PENDAHULUAN}

Arsitektur vernakular merupakan salah satu respon dalam pembangunan yang tumbuh dari masyarakat lokal (Harisdani \& Lindarto, 2020). Hal ini menggunakan teknik trial and error dan bergantung pada pengalaman serta sumber daya lokal untuk materialnya. Pengalaman dalam pembangunan ini berdasarkan budaya dan adat sudah diwariskan secara turuntemurun (Purwantiasning, 2020; Wiranto, 1999). Maka dari itu memunculkan suatu respon lingkungan fisik, sosial dan budaya pada masyarakat terutama dalam membangun rumah.

Rumah vernakular adalah artefak berupa rumah yang bangunannya menyerupai (menyontoh) bangunan rumah tradisional yang ada pada daerahnya, atau berdasarkan persepsi pemilik ataupun perancangnya tentang arsitektur tradisional tersebut (Mentayani \& Ikaputra, 2012; Roesmanto \& Haryanto, 2013). Rumah vernakular juga dapat sebagai wujud status sosial pemilik seperti halnya rumah tradisional (Kartono, 2005). 
Hunian untuk setiap keluarga mayoritas selalu bertambah dan berkembangi. Rumah vernakular juga berperan pada perkembangan dalam menyesuaikan kebutuhan pemilik yang juga dipengaruhi aktivitasnya dalam maupun luar rumah yang berdampak juga pada tata ruang, tipologi bentuk dan elemen arsitektural yang sudah ada sejak dahulu (Iswanto, 2008; Purwantiasning, 2020). Dalam studi hubungan antara lingkungan dan budaya serta konsep budaya telah dibuktikan secara luas untuk dapat dijelaskan dalam hubungan dengan lingkungan. Maka dari itu, Rapoport memperkenalkan konsep Dismantling (pemecahan menjadi lebih spesifik). Hal ini dapat mempermudah pembagian antara budaya dan lingkungan (Rapoport, 2008). Seperti pada kajian rumah vernakular yang ada di daerah Jabungan, Semarang menggunakan kajian pendekatan lingkungan, rancangan vernakular, tradisi, suasana dan sebagainya.

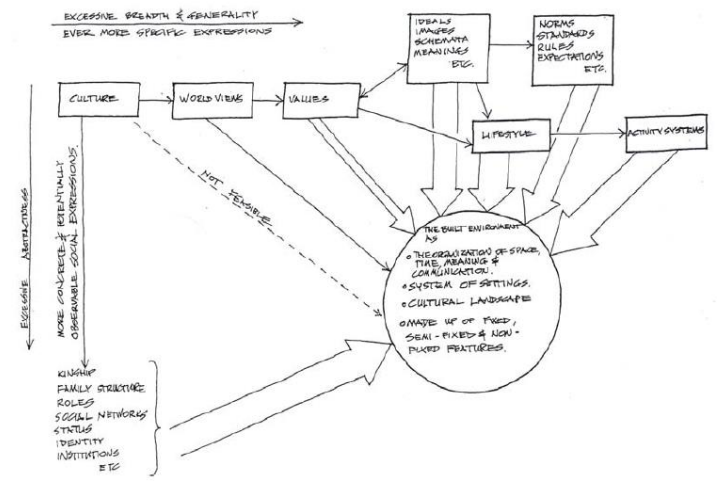

Gambar 1. Diagram konsep dismantling dalam hubungan budaya dan lingkungan.

(Sumber: Rapoport, 2008)

Menurut Rapoport (2008), dalam studi hubungan antara lingkungan dan budaya, konsep budaya (culture) telah dibuktikan terlalu luas dan abstrak untuk dijelaskan dalam hubungannya dengan lingkungan (environment). Tujuan dari konsep dismantling adalah untuk memecah aspek dan komponen dari budaya menjadi lebih spesifik dan menunjukkan semakin terdapat kemungkinan hubungan dan pengaruh terhadap lingkungan. Pendekatan diagram konsep dismantling oleh Rapoport, tidak hanya untuk memecah aspek aspek budaya menjadi lebih spesifik. Konsep tersebut juga berfungsi untuk mempelajari pengaruh aspek budaya (culture) yang sebelumnya tidak tampak menjadi tampak dalam lingkungan terbangun (environment). Aspek budaya tersebut bukan berarti dapat langsung terlihat nyata dalam fitur yang pasti.
Pengaruh aspek budaya terhadap lingkungan dapat terlihat dari aspek kualitas lingkungan, tatanan tertentu dalam penataan lingkungan, penekanan gradien tertentu, fleksibilitas, dan aspek - aspek lingkungan yang lain.

Berdasarkan hal tersebut, maka akan digali suatu budaya pada rumah vernakular yang tampak berdasarkan konsep dismantling pada salah satu teori Rapoport. Sehingga akan diperoleh suatu kajian bentuk tempat hunian yang memberikan suatu budaya (nilai, tradisi, adat, dan sebagainya) yang berhubungan dengan lingkungan di daerah sekitarnya.

\section{METODE PENELITIAN}

Penelitian ini menggunakan metode deskriptif analalitis. Metode ini memberikan gembaran pada objek yang diteliti melalui sempel atau data yang terkumpul kemudian melakukan analisis secara diskriptif dan membuat kesimpulan bersifat umum. Data diperoleh dari studi lapangan dan studi literature yakni wawancara dan dokumentasi pada Rumah di Jabungan, Semarang.

\section{HASIL DAN PEMBAHASAN}

\section{Tinjauan Lokasi}

Rumah vernakular mempunyai umur kurang lebih 50 tahun dan masih dalam kondisi baik hingga saat ini. Objek studi tersebut berlokasi di Jabungan, Semarang.

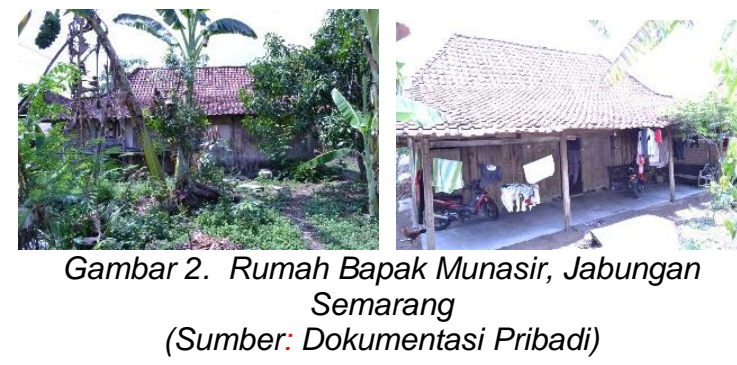

Rumah ini merupakan warisan dari orang tua Bapak Munasir (gambar 2). Rumah belum mengalami banyak perubahan, hanya pada bagian sisi kanan bangunan sudah diganti dinding dengan batu bata dan bagian belakang sudah ditambahkan ruang tambahan.

\section{Pola Tata Letak Bangunan}

Rumah utama dan tanah disekelilingnya tersebut merupakan rumah warisan secara turun temurun. Sehinga tetangga sekitar rumah utama masih dalam lingkup satu keluarga dan kerabat. 


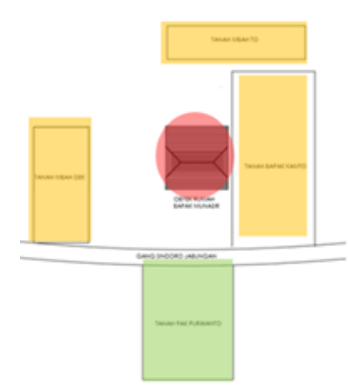

- Rumah utama (objek studi)

- Rumah keluarga dekat • Rumah baru

Gambar 3. Gambar Situasi Objek penelitian.

(Sumber: dokumentasi pribadi)

- Culture, Karakter situasi pada rumah dikelilingi oleh keluarga dekat pemilik.

- Word view, pandangan hidup dalam budaya tersebut adalah kedekatan keluarga yang ditentukan dalam suatu blok rumah-rumah.

- Values, nilai yang dijunjung adalah kedekatan dan membaur terutama sesama tetangga yang merupakan masih dalam ikatan saudara.

- Life style, gaya hidup orang pada sekitar objek studi memperkuat saling membantu sesama tetangga.

Selain itu pada aspek -aspek budayanya terdapat ekspresi budaya yang konkrit dan tampak yakni struktur keluarga yang terlihat dari warisan yang diberikan secara turun temurun sehingga menciptakan kekerabatan yakni dari saling tolong-menolong sesama masyarakat.

- Elemen Fixed: Rumah vernakular dan struktur keluarga,

- Non-Fixed Elemen: Hubungan interaksi manusia.

\section{Denah}

Pada objek studi tersebut terlihat susunan rumah ruang yang mempunyai pusat inti core yang di- sebut dengan dalem dan dikelilingi oleh soko guru (kolom utama). Seperti yang terlihat pada gambar berikut:

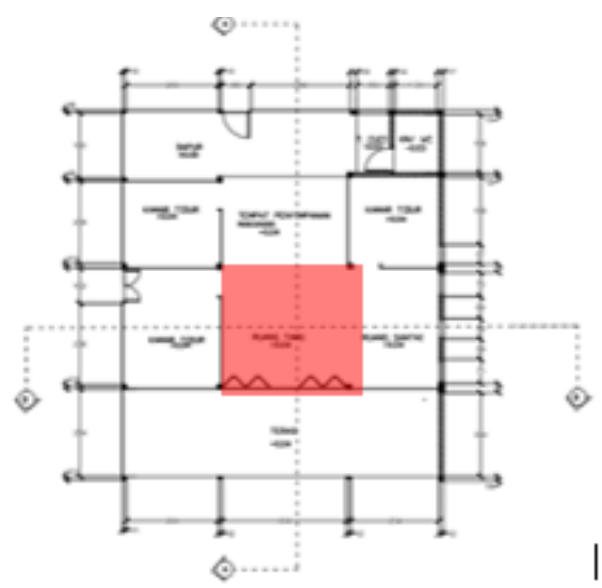

Gambar 4. Gambar Denah Objek Penelitian. (Sumber: dokumentasi pribadi)

- $\quad$ Culture, terdapat empat kolom sebagai inti pembentuk rumah.

- World view, pandangan hidup pada suatu inti di tengah bangunan menciptakan ruang yang dapat menjadi magnet bagi ruang-ruang yang lain.

- Value, nilai yang diambil pada suatu inti tersebut sebagai penakik kebersamaan dalam suatu lingkungan rumah.

- Ideas, harapan yang diinginkan adalah sebagai pembangun kebersamaan dalam rumah maupun orang sekitar.

- Live style, gaya hidup masyarakat yang selalu bersama yang membentuk suatu inti rumah (Dalem).

- Fixed element: Bagian inti ruang/ dalem soko guru

- Semi fixed elemen: Ruang-ruang dan perabotan rumah

- Non fixed elemen: orang berkumpul bersama .

\section{Tampak}

Pada tampak tersebut terlihat jelas bukaan terutama pada pintu depan atau pintu utama mempunyai bukaan yang sangat lebar dan mempunyai lebih dari 5 daun pintu.

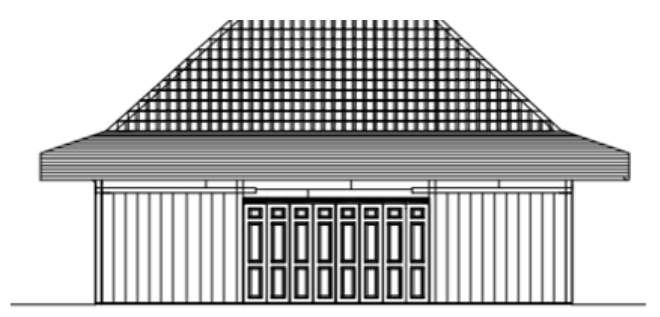

Gambar 5. Gambar Tampak Depan Objek Penelitian.

(Sumber: dokumentasi pribadi) 
- Culture, suatu budaya pada yang terlihat pada contoh tersebut adalah sebuah bukaan berupa pintu yang lebar

- World view, pandangan hidup pada sebuah bukaan adalah suatu jalan masuk yang mengundang kerabat atau tetangga untuk mendatangi / bersilaturahmi ke rumah tersebut

- Value, nilai yang diambil pada suatu bukaan tersebut adalah keterbukaan antar tetangga dan masyarakat lain dalam suatu lingkungan

- Lifestyle, gaya hidup pada masyarakat tersebut adalah mengayomi secara terbukan terhadap tetangga yang merupakan keluarga atau kerabat dekat.

- Fixed element: bangunan

- Semi fixed element: bukaan pada bangunan

- $\quad$ Non fixed element: keterbukaan pada sebuah bangunan.

\section{Atap}

Secara keseluruhan bentuk atap pada rumah vernakular di Jabungan adalah limasan dan kampungan yang merupakan suatu bagian dari kondisi ekonomi dan status kepemilikan tersebut.

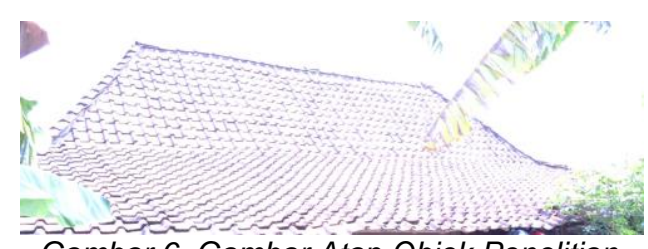

Gambar 6. Gambar Atap Objek Penelitian. (Sumber: dokumentasi pribadi)

- Culture, suatu budaya pada yang terlihat pada bentuk atap yang berupa limasan dan kampungan

- World view, pandangan hidup pada sebuah atap adalah suatu status sosial

- Lifestyle, gaya hidup pada masyarakat sebenarnya ingin menunjukan martabat mereka.

- Fixed element: atap rumah

- Non fixed element: status sosial pemilik.

\section{Dinding}

Dinding yang awal mulanya sebagai pembatas yang cukup disekat dengan papan, sekarang pada bagian tertertentu dinding beralih dengan batu bata. Selain itu, hampir pada semua bagian tetap mempertahankan dengan kayu hal ini merupakan pertimbangan dari rapuhnya kayu pada usia bangunan yang semakin tua.

Fixed element: dinding batu bata

- Semi fixed element : dinding kayu

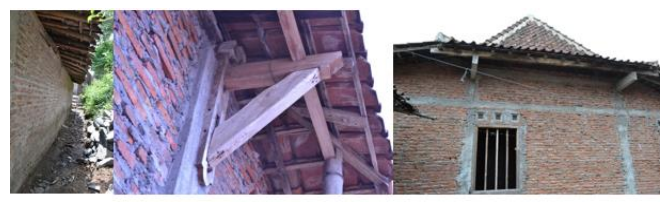

(a)

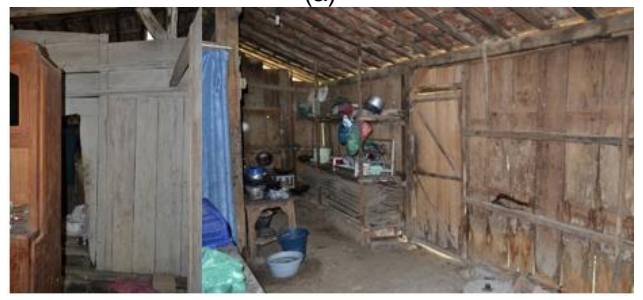

(b)

Gambar 7. Gambar Kondisi Dinding (a) batu bata; (b) dinding kayu Objek Penelitian. (Sumber: dokumentasi pribadi)

\section{KESIMPULAN}

Dalam perancangan arsitektur, banyak hubungan budaya dan rumah arsitektur vernakular pada daerah Jabungan Semarang yang terlihat pada objek studi tersebut adalah secara garis besar mengikuti rumah Joglo (rumah tradisional jawa tengah). Selain itu ada elemen-elemen pembentuk rumah menggunakan filosofi suatu kebersamaan dan keterbukaan dengan keluarga atau tetangga sekitarnya.

Inti dari sebuah rumah merupakan suatu titik kebersamaan dalam bertetangga maupun berkeluarga. Sedangkan keterbukaan terlihat dari lebarnya pintu dalam suatu rumah. Selain itu rumah juga sebagai ekspresi diri atau pemilik untuk menunjukkan status sosial pemilik yang terlihat dari elemen rumah terutama pada atapnya. Rumah vernakular terutama pada daerah Jabungan Semarang merupakan suatu elemen dari budaya yang terkait dengan lingkungan yang telah tercipta sehingga menciptakan suatu aktifitas (budaya lokal) yang dapat mempererat kerukunan antar warga. Sehingga hal ini seharusnya dapat dipertahankan dan dikembangkan agar nilainilai pada kehidupan sekelompok masyarakat masih mempertahankan suatu kebudayaan yang baik seperti saling membantu sesama.

\section{DAFTAR PUSTAKA}

Harisdani, D. D., \& Lindarto, D. (2020). Geriten 
Karo Sebagai Pembentuk Identitas Tempat. NALARs Jurnal Arsitektur, 19(1), $1-8$.

Iswanto, D. (2008). Aplikasi Ragam Hias Jawa Tradisonal Pada Rumah Tinggal Baru. Enclosure, 7(2), 90-97.

Kartono, J. L. (2005). Konsep Ruang Tradisional Jawa Dalam Konteks Budaya. Dimensi Interior, 3(2), 124-136. Retrieved from http://puslit2.petra.ac.id/ejournal/index.ph $\mathrm{p} / \mathrm{int} / \mathrm{article} / \mathrm{view} / 16388$

Mentayani, I., \& Ikaputra. (2012). Menggali Makna Arsitektur Vernakular: Ranah, Unsur, dan Aspek-Aspek Vernakularitas. Lanting Journal of Architecture, 1(2), 6869.

Purwantiasning, A. W. (2020). Tinjauan Kritis: Restorasi Minor dan Mayor Pada Hunian Tradisional Cagar Budaya di Indonesia Studi Kasus Rumah Tuo Kampai Nan Panjang Dan Rumah Wae Rebo. NALARs Jurnal Arsitektur, 19(1), 9-18.

Rapoport, A. (2008). Some Further Thoughts on Culture and Environment. International Journal of Architectural Research, 2(1), 16-39.

Roesmanto, T., \& Haryanto. (2013). Keberlanjutan Ruang Luar (Koefisien Dasar Bangunan Tradisional) Rumah Vernakular Pesisir Utara Jawa Tengah. MODUL, 13(2), 73-76.

Wiranto. (1999). ARSITEKTUR VERNAKULAR INDONESIA Perannya Dalam Pengembangan Jati Diri. Dimensi Teknik Arsitektur, 27(2). 
